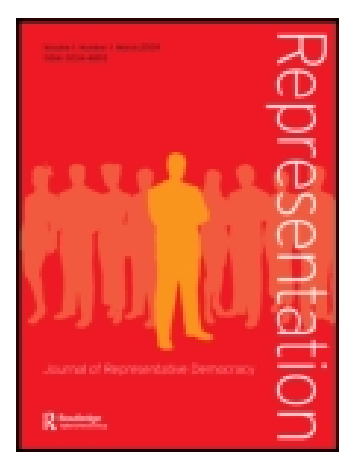

Representation

\title{
CHANGES AND CONTINUITIES IN THE TURKISH PARTY SYSTEM
}

\section{Ergun Özbudun}

To cite this article: Ergun Özbudun (2006) CHANGES AND CONTINUITIES IN THE TURKISH PARTY SYSTEM, Representation, 42:2, 129-137, DOI: 10.1080/00344890600736366

To link to this article: https://doi.org/10.1080/00344890600736366

$$
\text { Published online: } 23 \text { Aug } 2006 .
$$

Submit your article to this journal $₫$

LII Article views: 391

Citing articles: 13 View citing articles 4 


\title{
CHANGES AND CONTINUITIES IN THE TURKISH PARTY SYSTEM
}

\author{
Ergun Özbudun
}

\begin{abstract}
The article deals with the changes and continuities in the Turkish party system especially in the light of the 2002 parliamentary elections. It is argued that the victorious AKP (Justice and Development Party) is not a simple continuation of previous Islamist parties, but a new political force with a broad appeal to the former centre-right, centre, nationalist, as well as a portion of Islamist voters. The article also discusses the meanings of the terms left and right in Turkish politics.
\end{abstract}

At first sight, the parliamentary elections of 3 November 2002 seem to be a real turning point in Turkey's recent political history. For the first time, a party with Islamist roots became the governing party with 34.28 per cent of the votes and almost two-thirds of the parliamentary seats. For the first time since 1991, a single-party government was formed. For the first time since the transition to a multi-party system in 1946, only two parties are represented in parliament, the AKP (Justice and Development Party) and the CHP (Republican People's Party). ${ }^{1}$ Consequently, the fragmentation of seats index fell from 0.79 in 1999 to 0.46 in $2002 .^{2}$ On the other hand, the volatility index rose sharply from 19.9 in 1999 to an all-time high (54.45) in 2002. ${ }^{3}$ Of the six parties represented in the 1999 Parliament, five - DSP (Democratic Left Party), MHP (Nationalist Action Party), ANAP (Motherland Party), DYP (True Path Party) and SP (Felicity Party) - were not able to pass the ten per cent national electoral threshold. The first three parties were the coalition partners in the Ecevit government that ruled Turkey from 1999 to 2002. Of the deputies in the 2002 Parliament, 81 per cent were newcomers who had no previous parliamentary experience, and 90 per cent had not been deputies in the 1999 Parliament.

\section{Continuities in Voting Patterns}

The radical changes brought about by the 2002 elections conceal, however, important continuities in the Turkish party system. Table 1 shows a remarkable stability in voting patterns between the right and the left blocs. The meaning of the terms 'left' and 'right' will be discussed in detail below. Since the transition to a multi-party system in 1946, Turkey has had 14 general parliamentary elections (excluding the controversial and semi-free elections of 1946). In all these elections, the right parties obtained a clear majority with a voting percentage ranging between 55.7 in 1977 and 68.5 in 1995 . The average vote percentage of the right parties over these years is 63.0, while that of the left parties is 34.3. In fact, the real percentage of the left parties may be even lower than that, since the Kurdish nationalist-oriented HADEP (now DEHAP), which is classified as a left party in this analysis, cannot easily be placed on a left-right continuum. The left parties passed the 40 per cent line only twice in this period, in 1957 and 1977. It should be recalled that both elections were held in extraordinary circumstances when the future of 
TABLE 1

Voting percentages for right and left parties, 1950-2002

\begin{tabular}{lll}
\hline & Left & Right \\
$1950^{\mathrm{a}}$ & 39.9 & 56.3 \\
$1954^{\mathrm{b}}$ & 35.3 & 62.3 \\
$1957^{\mathrm{c}}$ & 41.1 & 58.8 \\
$1961^{\mathrm{d}}$ & 36.7 & 62.5 \\
$1965^{\mathrm{e}}$ & 30.4 & 65.1 \\
$1969^{\mathrm{f}}$ & 32.9 & 61.5 \\
$1973^{\mathrm{g}}$ & 34.4 & 62.2 \\
$1977^{\mathrm{i}}$ & 41.4 & 55.7 \\
$1983^{\mathrm{j}}$ & 30.5 & 68.4 \\
$1987^{\mathrm{k}}$ & 33.2 & 65.5 \\
$1991^{\mathrm{l}}$ & 31.6 & 68.0 \\
$1995^{\mathrm{m}}$ & 29.5 & 68.5 \\
$1999^{\mathrm{n}}$ & 35.7 & 58.5 \\
$2002^{\circ}$ & 28.0 & 68.1 \\
\hline
\end{tabular}

a: Left: CHP (Republican People's Party); Right: DP (Democrat Party); MP (Nation Party)

b: Left: CHP; Right: DP, CMP (Republican Nation Party)

c: Left: CHP; Right: DP, CMP, HP (Freedom Party)

d: Left: CHP; Right: AP(Justice Party), CKMP (Republican Peasant Nation Party), YTP (New Turkey Party)

e: Left: CHP, TiP (Turkish Workers' Party); Right: AP, CKMP, YTP, MP (Nation Party)

f: Left: CHP, TiP, BP (Unity Party); Right: AP, YTP, MP, CGP (Republican Reliance Party), MHP (Nationalist Action Party)

g: Left: CHP, BP; Right: AP, CGP, MHP, DP (Democratic Party), MSP (National Salvation Party)

i: Left: CHP; Right: AP, CGP, DP, MHP, MSP

j: Left: HP (Populist Party); Right: ANAP (Motherland Party), MDP (Nationalist Democracy Party) k: Left: SHP (Social Democratic Populist Party), DSP (Democratic Left Party); Right: ANAP, DYP

(True Path Party), RP (Welfare Party), MHP

I: Left: SHP, DSP; Right: ANAP, DYP, RP (in alliance with MHP)

m: Left: CHP, DSP, HADEP (People's Democracy Party); Right: ANAP, DYP, RP, MHP

$\mathrm{n}$ : Left: CHP, DSP, HADEP; Right: ANAP, DYP, MHP, FP (Virtue Party)

o: Left: CHP, DSP, YTP (New Turkey Party), DEHAP (Democratic People's Party); Right: AKP, DYP, MHP, GP (Young Party), ANAP, SP (Felicity Party), BBP(Grand Unity Party)

Parties receiving less than 1 percent of the vote are not included in the calculations.

the democratic regime seemed in grave danger and many centrist voters voted for the CHP with the hope of preventing a breakdown of the regime.

Frequent changes in party names also conceal a basic stability in voting patterns. Such changes were directly caused by the 1960 and the 1980 military interventions: the former banned the DP, and the latter banned all the existing parties. On the other hand, there is little doubt that the JP is a continuation of the DP, and the DYP is a continuation of the JP. Similarly on the left, the HP (Populist Party) and the SHP (Social Democratic Populist Party) were clearly successors to the CHP, and they were finally merged in a reborn CHP. ANAP and the AKP are more debatable cases. In fact, Turgut Özal, the founder of ANAP, often proudly asserted that ANAP was not a continuation of any of the older parties and that it brought together four pre-existing political tendencies (centre-right, centre-left, Islamist right, and nationalist right) under its own roof. Statistical analysis of party votes in the 1983 elections did not show strong correlations between the ANAP vote and votes for former parties in previous elections, thereby lending support to Özal's argument that 
ANAP was a new actor in Turkish politics (Ergüder and Hofferbert 1988, 81, 102; Ergüder 1991). There is little doubt, however, that for all practical purposes ANAP can be considered a centre-right party.

The case of the AKP is even more arguable. The AKP, like ANAP, does not claim descent from any of the older parties. On the other hand, the top leadership of the party, including Prime Minister Erdoğan, Foreign Minister Gül and Arınç, the Speaker of the Parliament, occupied important positions in the RP (Welfare Party) and its successor FP (Virtue Party). Ideologically, they were attached to an Islamist world-view. Many AKP deputies and many of its local cadres also had their political origins in the RP-FP movement. However, many ministers in the new cabinet do not come from an Islamist background. Thus the important ministries of justice, the interior, labour and social security, industry and trade, and culture and tourism are controlled by former ANAP members. The minister of national education comes from a DYP background, and one of the ministers of state from a MHP one. Two important parliamentary committees (justice and foreign affairs) are chaired by former leading members of the DYP. The cabinet and the AKP parliamentary group also include a good number of political novices with no previous party experience.

This coalitional character is also supported by the analysis of voting patterns in the 2002 elections. A 2002 pre-election survey showed that only 27.4 per cent of AKP voters had voted for the FP (Virtue Party) in 1999; a surprisingly high 21.9 per cent had voted for the MHP, 9.2 per cent for ANAP, 7.3 per cent for the DYP, and 6.9 per cent for the DSP. Similarly, 57 per cent of former FP voters, 30.5 of former MHP voters, 16.8 per cent of former DYP voters, 16.7 per cent of former ANAP voters and 10.8 per cent of former DSP voters expressed their intention to vote for the AKP in the 2002 elections (TÜSES 2002, 70 1). These findings are strongly corroborated by those of two other survey research organisations, ANAR and SAM, in surveys carried out in October 2002. ${ }^{4}$ Thus, the AKP seems to have received substantial support from the former voters of the two centre-right parties (ANAP and DYP) and those of the ultra-nationalist MHP, in addition to more than half of former Islamist FP voters. The rest of the latter seem to have remained loyal to the Erbakan tradition now represented by the SP (Felicity Party), which received only 2.5 per cent of the vote in the 2002 elections. Surprisingly, some 10 per cent of former voters for the leftist DSP also indicated their intention to vote for the AKP. On the basis of these findings, it may be concluded that the AKP appears to have successfully rebuilt the Özal (ANAP) coalition including former centre-right voters, moderate Islamists, moderate nationalists and even a certain segment of the former centre-left. Sociologically speaking, the AKP coalition is based on the support of much of the rural population, artisans and small traders in the cities, urban slum-dwellers and the rapidly rising Islamist bourgeoisie. The AKP is the only national party that can compete with the ethnically-oriented DEHAP (previously HADEP) in the mostly Kurdish-populated south-eastern region. Obviously, this is a rather heterogeneous coalition, socially and politically. Only time will tell if the AKP will be able to maintain it in the long run, a formidable task which ANAP failed to accomplish.

\section{Ideological Continuities and Discontinuities}

Since the beginning of the multi-party period, Turkish politics have always been dominated by centre-right parties. Although none of these parties were ideological 
entities in the strict sense, the elements of their overall world-view can be described as respect for the traditional values (including religion), nationalism, reliance on local initiative and sensitivity to local demands and a belief in the superiority of the national will. Thus their world-view represented a mixture of conservative and liberal elements; conservative in the sense of respect for national, traditional and religious values, and liberal in the sense of opposition to the domination of an overpowering state and especially to that of a strong, central, bureaucratic, domineering state elite.

When we study the ideology of the AKP, we observe significant continuities with the world-view of the former centre-right parties. Although the top leadership of the AKP comes from Islamist roots, the new party has carefully refrained from using Islamic themes and has insisted that it is not a party based on religion. The AKP leaders have even refused to call themselves 'Muslim democrats' and prefer the label 'conservative democrats'. In a document entitled 'The AKP and Conservative Democracy' (AK Parti 2003), prepared and distributed by the central headquarters of the party, the AKP's notion of conservative democracy is explained in detail. In his introduction to this manifesto, party leader Recep Tayyip Erdogan stated the AKP's opposition to the notion of 'political community which radicalises politics', a clear reference to the practice of the older Islamist parties, and claimed that the AKP had become 'the indisputable single force of the centre-right'. He also made it clear that the AKP's understanding of conservatism was not against change, but that it advocated change 'in the sense of development and progress':

The AKP emphasises a modern conservatism open to innovation, in place of the conservatism of the past which was built on the status quo. The AKP advocates a change based on an evolutionary, gradual and natural societal transformation. The AKP's understanding of conservatism is not the preservation of the existing institutions and relationships, but the preservation of certain values and acquisitions. Such preservation does not mean being closed to change and progress, but means adaptation to development without losing the essence.

With regard to secularism, Erdoğan states that the AKP,

while attaching importance to religion as a social value, does not favour a [style of] politics based on religion, the transformation of the state on an ideological basis and organisation on the basis of religious symbols. Politics based on religion, using religion as an instrument, and pursuing an exclusionary policy in the name of religion will harm both social peace and political pluralism, as well as religion. There is a very serious difference between being a party which attaches importance to religion and to the pious people and accepts the social functions of religious values, and being a party which aims to transform the society by force with the aid of the state apparatus by transforming religion into an ideology.

Throughout the manifesto, such democratic and liberal values as limited government, a free-market economy, strong civil society, human rights, dialogue and toleration are constantly emphasised.

Thus the AKP's version of conservative democracy does not seem to be fundamentally different from the ideologies of Western conservative or Christian democratic parties, or from those of the previous centre-right parties in Turkey. However, such compatibility should also be tested at the level of voters' values. The 
basic conclusion of a number of public opinion surveys is that the values of AKP voters are somewhat different, but not too much different, from those of the other centre-right and nationalist parties. A good measure of the strength of political Islam is the degree of voters' support for a government based on the rules of Islamic law (sharia). A 1996 TÜSES survey showed that 26.7 per cent of respondents wanted a sharia-based government, while 58.1 per cent said no and 15.2 were undecided or had no opinion. In a 1998 survey by the same organisation, the percentage of the pro-sharia voters fell to 19.8 per cent, while 59.9 per cent were against and 20.2 per cent were undecided. Finally, in a 2002 survey, the percentage of pro-sharia voters was only 9.9; those who were against constituted 60.7 per cent and the undecided voters 29.4 per cent (TÜSES 2002, 22-3). Interestingly, the sharp fall in the percentage of pro-sharia voters did not correspond to a similar rise among anti-sharia voters, but there was a substantial rise in the undecided/no opinion category. This may be due to the confusion resulting from the closure of the RP and the FP by the Constitutional Court, and to the changing attitude of the AKP with regard to religion. Also it may be argued that not all pro-sharia voters may necessarily favour the literal application of all sharia rules (Heper 2003).

On the other hand, there seems to be a significant difference between the proportion of pro-sharia respondents among AKP voters and those of the other parties. The 2002 TÜSES survey showed that 22.8 per cent of AKP voters were in favour and 43.5 per cent were against, while 33.7 per cent expressed no opinion. The proportion of prosharia voters is much lower in the traditional centre-right and nationalist parties (6.6 in DYP, 6.7 in ANAP, 8.4 in MHP) but, as expected, much higher in the SP (Felicity Party). Nevertheless, it is interesting that close to half of AKP voters did not favour a sharia-based government. When the AKP figures are compared with those of the predecessor parties, the RP and FP (according to a 1996 TÜSES survey their percentage of the pro-sharia voters was 61.3), such comparison lends support to the argument that the AKP is not simply a continuation of predecessor Islamist parties (TÜSES 2002, 48-9).

While these findings indicate a positive trend towards a reconciliation between political Islam and the secular state in Turkey, it should be pointed out that Turkish Islam is not as entirely free of anti-liberal elements as some observers present it. A 1999 survey showed that 58.9 per cent of respondents think that all Muslim women should cover their heads; 57.1 per cent are against short skirts; 66.5 per cent are in favour of banning books that deny God or the Prophet; 70.5 per cent favour the banning of alcohol sales in the month of Ramadan; and 66.4 per cent think that working hours should be arranged in accordance with Friday prayers (Çarkoğlu and Toprak 2000, 59). Such high percentages indicate that religiously-inspired conservative values are quite strong not only among the voters of Islamist parties, but also among those of centre-right and nationalist parties. A 2002 survey indicated that among all respondents, the percentage of those who think that all Muslim women should cover their heads is 30, while 64 per cent think that this should be left to the individual's choice. Among AKP voters, these percentages are 45 (considerably higher than the national average) and about half respectively. The same survey revealed that 65 per cent of AKP voters are in favour of regulating adultery according to Islamic law; similar percentages are 52 for matters of inheritance, 57 for abortion, 51 for crimes and 72 for parent-child relations; 60 per cent of the AKP voters are against interest-taking. ${ }^{5}$ Thus it appears that a majority of AKP voters share religiouslyinspired conservative values. The AKP government's unsuccessful attempt to recriminalise adultery in autumn 2004 can be considered a gesture to its conservative voter base. 
A final hypothesis to be tested is the 'protest vote' hypothesis. The protest vote hypothesis has been put forward with regard to the 1995 and 1999 elections to explain the sudden rise of the RP, and the MHP (Tachau 2002, 49-50). However, other studies of the 1999 elections failed to discover a correlation between the RP/FP and MHP vote and the feeling of relative deprivation. Thus, argues Esmer, 'the proportion of the FP or the MHP supporters who are not at all satisfied with their incomes is about the same as the proportion who are very satisfied. Likewise, there is no correlation between subjective happiness and the vote for these parties' (Esmer 2002, 101-2). Similar questions were asked in pre-and post-elections surveys in 2002. Esmer's findings indicate that the proportion of the AKP voters who feel subjectively deprived (14 per cent) is only very slightly higher than the average for all voters (12 per cent). Similarly, the percentage of those who reported that they had no problem in maintaining their life standards is 26 among the AKP voters and 30 for all voters. ${ }^{6}$ Other studies have shown, however, that the AKP got the votes of a substantial proportion (29.9 per cent) of those who considered themselves 'deprived' or 'oppressed' (the Turkish word ezilenler corresponds more closely to the latter). ${ }^{7}$ Nevertheless, it is not clear whether this term refers to economic hardships or to a feeling of being excluded or alienated by the overpowering state.

The above analysis indicates that the AKP is a broadly-based national party that appeals not only to the voters of previous Islamist parties, but also to a wide segment of the centre-right, even centrist, voters. Its political discourse, emphasising democratisation, human rights and Turkey's accession to the EU, is much closer to that of the traditional centre-right parties than to that of the previous Islamist parties. However, strong religiously-inspired conservative attitudes prevail among a majority of AKP voters, which puts the AKP government in a delicate position between the need to satisfy them and to pursue its modernising policies.

\section{What Do the Terms 'Left' and 'Right' Mean in Turkish Politics?}

It has often been pointed out that the main dividing line in Turkish politics is a centre-periphery cleavage. Most students of Turkish politics agree that the origins of the Turkish party system lie in a centre-periphery conflict, which pitted a nationalist, centralist, laicist, cohesive state elite against a 'culturally heterogeneous, complex, and even hostile periphery' with religious and anti-statist overtones. ${ }^{8}$ Even though it may be argued that the centre is no longer as united and cohesive as it was, and that the periphery was fragmented among many competing centre-right and right parties in the 1990s, the present semi-two-party configuration of the Turkish party system can still be accurately described as being based on a centre-periphery conflict, with the CHP representing the centre and the AKP the periphery.

How can this conclusion be reconciled with studies claiming that the best predictor of voters' behaviour in Turkey is their self-identification on a left-right scale? Thus Esmer argues that

the left-right ideological position is one of the leading indicators -if not the most important one- of voter preference. ... In the face of these data, it is very hard to confirm the frequently expressed argument that, in the 1990s, the left and the right have lost their meanings and have become devoid of their traditional contents (Esmer 2002, $99,103)$. 
It can be questioned, however, whether this correlation is somewhat spurious, since it is not clear if the voters prefer certain parties because of their self-identification on a leftright scale or because they identify themselves as such because of their identification with a certain party. Even if the correlation is not spurious, we still have to clarify the meanings of the terms left and right in Turkish politics, since they are very different from their meanings in Western democracies.

Traditionally, in Western democracies, the left-right dimension in politics is associated with party positions on socio-economic policy. Left parties support greater public ownership of the means of production, a stronger governmental role in economic planning, redistribution of wealth from the rich to the poor and the expansion of governmental social welfare programmes, while parties of the right support the opposite (Lijphart 1984, 129). Interestingly, studies emphasising the importance of the left-right division in Turkish politics mention none of these policy dimensions, but concentrate on cultural-religious issues. ${ }^{9}$ Thus Esmer reports that

the CHP support was less than 1 per cent among those who chose religious values over other alternatives and more than 18 per cent among those who picked secularism as the most important value. The FP support was the highest among those who chose religious values and lowest among those who chose secularism. Nationalist values, not surprisingly, were the favourite among the MHP voters (Esmer 2002, 102).

It appears that in the Turkish context, the 'right' refers to a commitment to religious, conservative and nationalist values, while the 'left' is defined primarily in terms of secularism. This observation is supported by an analysis of voting patterns, as well as of parties' positions on socio-economic issues. Survey research has consistently shown that the CHP vote over the years has been positively correlated with high socio-economic status (SES) and high levels of education (a paradoxical situation for a 'leftist' party) while the vote for the Islamist and nationalist parties correlated negatively with high SES and the years of schooling (Esmer 2002, 101-2). ${ }^{10}$

Finally, it should be stressed that Turkish parties' positions on socio-economic issues do not correspond to the standard left-right cleavage. The centre-right and Islamist parties in Turkey have always shown a sensitivity to the plight of low-income groups and favoured a paternalistic notion of the state. ${ }^{11}$ At present, the AKP's ideology is not alien to a concern for social justice and a social welfare state, even though it strongly emphasises a market economy.

This analysis suggests that the AKP is closer to the centre-right tradition in Turkey rather than being a continuation of the previous Islamist parties. Its political discourse and voter base reflect a much broader appeal to wide segments of Turkish society. Thus the radical but superficial changes in the Turkish party system should not lead us to ignore certain basic continuities.

\section{NOTES}

1. Mehmet Ağar, an independent deputy elected from the province of Elazığ, later became the leader of the DYP (True Path Party) and was joined by three other members of Parliament. Thus the DYP is now a third party represented in Parliament. 
2. The 'Fragmentation' index is computed by subtracting the sum of the squares of the percentages of party votes (or seats) (written in decimals) from 1 . The index ranges between 0 and 1; 0 indicates no fragmentation, and 1 indicates extreme fragmentation.

3. 'Volatility' is the sum of the absolute value of all changes in the percentage of votes cast for each party since the previous election divided by two. In computing the volatility index, I treated the AKP as a new party for reasons to be explained below, and the SP (Felicity Party) as the successor to the RP (Welfare Party) and the FP (Virtue Party).

4. Taha Akyol, AKP'nin Arkasında Ne Var? (What is behind the AKP), Milliyet (daily), 19 Oct. 2002. See also Yılmaz Esmer, 3 Kasım Analizi (The Analysis of 3 November), Milliyet, 18 Nov. 2002. Esmer estimates that some one-fourth of former DSP voters voted for the AKP in 2002.

5. Esmer, 3 Kasım Analizi, Milliyet, 17 Nov. 2002.

6. Esmer, 3 Kasım Analizi, Milliyet, 19 Nov. 2004.

7. Akyol, AKP'nin Arkasında Ne Var? Milliyet, 17 Oct. 2002.

8. Quotation is from Kalaycıoğlu 1994, 403. Şerif Mardin was the first Turkish scholar to emphasise the importance of the centre-periphery cleavage in Turkish politics (Mardin 1972). See also Özbudun 1976, chapter 2; Heper 1980.

9. For example, Esmer's questionnaire does not include a single item on socio-economic issues (Esmer 2002).

10. Esmer 2002, 100-1; Esmer, 3 Kasım Analizi, Milliyet, 18, 19 Nov. 2002; Akyol, AKP'nin Arkasında Ne Var? Milliyet, 18 Oct. 2002; TÜSES 2002, 47.

11. Almost three decades ago a leading Turkish economic historian described the basic cleavage in Turkish politics as one between the Westernist-secularist camp and the Islamist-Easternist camp. More controversially, he asserted that the former represented the right and the latter the left (Küçükömer n.d., 82).

\section{REFERENCES}

AK PARTI. 2003. Ak Parti ve Muhafazakar Demokrasi (The AKP and conservative democracy). Ankara: AK Parti.

ÇARKOĞLU, ALI and BINNAZ TOPRAK. 2000. Türkiye'de, Din, Toplum ve Siyaset (Religion, society and politics in Turkey). İstanbul: Tesev Yayınları.

ERGÜDER, ÜSTÜN. 1991. The Motherland Party, 1983-1989. In Political parties and democracy in Turkey, edited by Metin Heper and Jacob M. Landau. London: I.B. Tauris: 152-69.

ERGÜDER, ÜSTÜN and RICHARD I. HOFFERBERT. 1988. The 1983 general elections in Turkey: Continuity or change in voting patterns? In State, democracy, and military: Turkey in the 1980s, edited by Metin Heper and Ahmet Evin. Berlin: Walter de Gruyter: 81-102.

ESMER, YILMAZ. 2002. At the ballot box. Determinants of voting behavior. In Politics, parties, and elections in Turkey, edited by Sabri Sayarı and Yılmaz Esmer. Boulder, CO, and London: Lynne Rienner Publishers: 91-114.

HEPER, METIN. 1980. Center and periphery in the Ottoman Empire with special reference to the nineteenth century. International Political Science Review 1(1): 81-105.

. The victory of the Justice and Development Party in Turkey. Mediterranean Politics 8(Spring 2003): 127-34.

KALAYCIOĞLU, ERSIN. 1994. Elections and party preferences in Turkey: Changes and continuities in the 1990s. Comparative Political Studies 27(Oct.): 402-24. 
KÜÇ̋̈KÖMER, IDRIS. n.d. Düzenin Yabancılaşması: Batılaşma (The alienation of order: Westernisation). İstanbul: Ant Yayınları.

LIJPHART, AREND. 1984. Democracies: Patterns of majoritarian and consensus government in twentyone countries. New Haven, $\mathrm{CT}$, and London: Yale University Press.

MARDIN, ŞERIF. 1972. Center-periphery relations: A key to Turkish politics. Daedalus (Winter): 169-90.

ÖZBUDUN, ERGUN. 1976. Social Change and political participation in Turkey. Princeton, NJ: Princeton University Press.

TACHAU, FRANK. 2002. An overview of electoral behavior: Toward protest or consolidation of democracy. In Politics, parties, and elections in Turkey, edited by Sabri Sayarı and Yılmaz Esmer. Boulder, CO, and London: Lynne Rienner Publishers: 33-54.

TÜSES. 2002. Türkiye'de Siyasi Partilerin Yandaş/Seçmen Profili (Supporter/voter profiles of political parties in Turkey). İstanbul: TÜSES.

Ergun Özbudun is professor of political science and constitutional law at Bilkent University, Ankara. His most recent book in English is Contemporary Turkish politics: Challenges to democratic consolidation (Boulder, CO: Lynne Rienner, 2000). E-mail: guvenay@bilkent.edu.tr 